
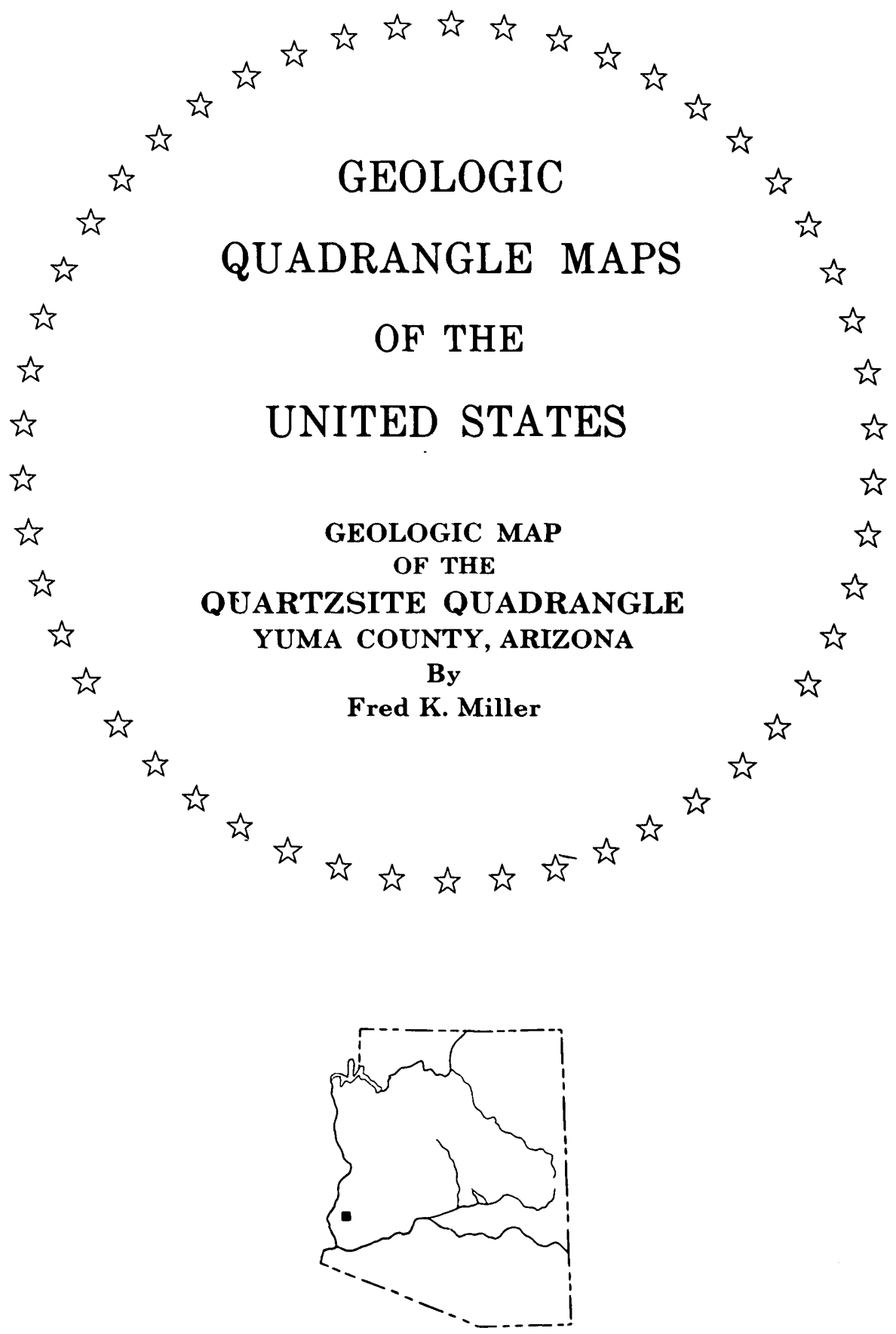

QUADRANGLE LOCATION 


\title{
GEOLOGIC MAP OF THE QUARTZSITE QUADRANGLE, YUMA COUNTY, ARIZONA
}

\author{
By Fred K. Miller
}

\section{PRECAMBRIAN ROCKS}

Quarlz monzonite.-An area of about 4 square miles in the central part of the quadrangle is underlain by an even-grained biotite quartz monzonite. The pluton is in fault contact with all rocks except the Precambrian or Mesozoic metavolcanic sequence to the south.

Both feldspars in the rock are highly altered. Biotite is in various stages of chloritization and has probably been recrystallized at least once. The south half of the body is more leucocratic than the north half and may in fact be a separate intrusion.

L.eon T. Silver, using lead-isotope methods on zircon, has calculated an age of 1730 to 1750 m.y. for the quartz monzonite.

Coarse-grained quartz monzonite. - Very coarse grained biotite quartz monzonite underlies the low hills near the juncture of Italian Wash and Apache Wash. North and west of Black Mesa, Cambrian sedimentary rocks nonconformably overlie the same body. Other contacts are faulted. West of Apache Wash some of the rock is medium to coarse grained and contains hornblende. All feldspar is highly altered, and biotite and hornblende chloritized.

\section{PRECAMBRIAN OR MESOZOIC ROCKS}

Metavolcanic rocks.-An area of about 5 square miles in the central and south-central part of the quadrangle is underlain by mildly metamorphosed rhyolitic to dacitic intrusive, flow, and tuffaccous rocks. Although the section is probably repeated by undetected fatting, a maximum thickness of 11,000 feet for the stratified part of unit was calculated from outcrop width. Some of the rock is sheared and in places is schistose. Color is variable from dark green to light gray. Quartz and plagioclase phenocrysts occur in an aphanitic matrix of quartz, plagioclase, chlorite, muscovite. and opaque minerals. The tentative age assignment of Precambrian or Mesozoic is based on lithologic similarities with both older Precambrian rocks of central Arizona, and rocks to the west that are thought to be of Mesozoic age.

\section{PALEOZOIC(?) ROCKS}

Five lithologic units found only in a one-square-mile area just south of U.S. Highway $60-70$ have undergone a style and degree of deformation unique among the rocks in the Quartzsite quadrangle. These rocks have undergone extreme plastic deformation as contrasted to brittle deformation common in all other rocks in the quadrangle. Although highly deformed, some of the units in the Paleozoic(?) rocks are similar to, and probably correlative with, formations in the fossiliferous Paleozoic section north and west of Black Mesa. Unit 1 is possibly equivalent to parts of the Martin(?) Formation and Escabrosa Limestone, unit 2 to the Supai Formation, and unit 4 to the Coconino Sandstone. Unit 3 is not represented in the fossiliferous Paleozoic section, and unit 5 is probably part of the Escabrosa Limestone faulted up against unit 4 .

However, because of differences in stratigraphy and deformational history, correlation between the Paleozoic(?) rocks and the Paleozoic section north of Black Mesa, although considered reasonable, is not regarded as positive.

Unit 1.-About 150 to 300 feet of dolomite and dolomitic limestone is faulted against Precambrian quartz monzonite. The rock is gray and tan, and in places chert bearing. Most stratification has been destroyed by deformation, but where recognizable, the rock appears to be thick to massively bedded.
Unit 2.-About 400 feet of thinly interbedded carbonate, calcareous quartzite, and quartzite structurally, and probably stratigraphically, overlie unit 1. Although most beds are less than an inch thick, some quartzite beds are as thick as 10 feet. The rock is cream colored to pink. Near the top, the unit becomes increasingly chloritic and grades upward into the schist of the overlying unit.

Unit 3.-Unit 3 is about 450 feet thick, predominantly quartzalbite-muscovite-chlorite schist with interbeds up to 10 feet thick which resemble unit 2. Primary features preserved in the schist suggest that the rock was predominantly a fine-grained sedimentary clastic rock with either interbeds of extrusive volcanic flows or intrusive hypabyssal sills.

Unit 4.-A bout 400 feet of medium- to massively bedded vitreous quartzite overlie unit 3 . The contact appears to be gradational. The quartzite is light tan to white, well sorted, and quite pure.

Unit 5.-Unit 5 is a tan, massively bedded carbonate rock. Part of the carbonate contains irregularly distributed chert masses, but much of the unit is free of chert. As near as can be estimated, owing to its poorly bedded character, about 400 feet of the unit is preserved. The contact between unit 4 and unit 5 appears to be a fault. The upper contact is a fault which places unit 5 against unit 3

Paleozoid?) rocks and Precambrian or Mesozoic rocks, undifferentiated.-Rocks probably belonging to the Precambrian or Mesozoic metavolcanic unit. and the Paleozoic(?) numbered units are found east and west of Scadden Mountain and south of Granite Mountain. These rocks are highly deformed dolomite and sheared metavolcanic rock. For various reasons, it was not possible to reliably assign these rocks to any of the other units.

\section{PALEOZOIC ROCKS}

North of Black Mesa, a section of limestone, dolomite, and quartzite is divisible into seven formations. Because of the distances to known Paleozoic sections, correlation is a major problem. There are no well-documented Paleozoic rocks within 100 miles of the Plomosa Mountains. A partial section, similar to that in the Plomosa Mountains, but presenting the same correlation problems, is present in the Little Harquahala Mountains 25 miles to the east.

The upper three formations of the section north of Black Mesa are similar to the Supai Formation. Coconino Sandstone, and Kaibab Limestone of the Grand Canyon section. P. T. Hayes and $F$. G. Poole first recognized that the lower four formations appear to more closely resemble the Bolsa Quartzite, Abrigo Formation, Martin Limestone, and Escabrosa Limestone of southeastern Arizona (written commun., 1966).

Bolsal?) Quartzite.-About 65 feet of quartzite rests nonconformably on coarse-grained Precambrian quartz monzonite in the wash immediately north of the Six Price mine. This rock strongly resembles the Cambrian Bolsa Quartzite (Ransome, 1904, p. 28) in southeastern Arizona. Bedding thickness ranges from an inch to about 3 feet, and color from light tan to white. Grain size varies from less than $0.1 \mathrm{~mm}$ to over $10 \mathrm{~mm}$. Almost all clasts are well rounded. Crossbedding and minor graded bedding are present, but rare.

Abrigo(?) Formation.-Dark-purple, green, and black sandy shale with thin interbeds of fine-grained impure quartzite overlies the Bolsa(?) Quartzite and is tentatively correlated with the lower member of the Cambrian Abrigo Formation as used by Cooper and Silver $(1964$, p. 47). No fossils were found in this 
unit except for what appeared to be animal tracks or worm trails along the interfaces between quartzite and shale beds. Thickness of the formation is about 150 feet.

Martin(?) Formation.-About 325 feet of dolomitic limestone, dolomite, and sandy dolomite, tentatively correlated with the Devonian Martin Formation as used by Cooper and Silver (1964, p. 53), overlie the Abrigo(?) Formation. The time hiatus between the deposition of these two formations is not reflected in any apparent unconformity. Bedding ranges in thickness from about 6 inches to 3 feet. Color is various shades of gray, although a number of tan, brown, and almost black beds are present. No fossils were found in this unit.

Escabrosa Limestone.-Overlying the Martin(?) Formation is about 415 feet of dolomite, limestone, and cherty limestone which is correlated with the Mississippian Escabrosa Limestone of southeastern Arizona (Ransome, 1904, p. 42; and Hayes and Landis, 1965, p. F20). The lower half of the Escabrosa Limestone in the Quartzsite quadrangle is massively bedded, light-gray, tan-weathering, sandy dolomite. The upper half is cherty limestone and limestone conglomerate with only small amounts of interbedded dolomite. Fossils collected by F. G. Poole from these beds and identified by W. J. Sando and Helen Duncan include Syringopora surcularia Girty and Vesiculophyllum cf. $V$. incrassatum (Easton and Gutschick). Both are common to the Mississippian Escabrosa and Redwall Limestones.

Supai Formation.-Rocks closely resembling the Supai Formation of Permian age overlie the Escabrosa Limestone disconformably. Above the contact is 1 inch to 1 foot of lenticular basal conglomerate. The lower half of the formation is white, pink, and maroon quartzite with some interbedded limestone and sandy red mudstone. The upper half of the unit contains only minor amounts of limestone. The formation is 550 feet thick and unfossiliferous in the Plomosa Mountains.

Coconino Sandstone.-The Coconino Sandstone is 660 feet thick in the Plomosa Mountains and consists of medium- to massively bedded, white to gray vitreous quartzite. Thin laminations are visible on some weathered surfaces. The clasts are medium grained, well sorted, and fairly well rounded. In the upper half of the formation, large-scale crossbedding is found locally. The quartzite rests with apparent conformity on the Supai Formation.

Kaibab Limestone.-About 670 feet of chert-bearing limestone correlated with the type Kaibab Limestone overlie the Coconino Sandstone in apparent conformity. The top of the formation is removed by an intrusive dacite porphyry. The lower part of the formation is light tan and gray and contains irregularshaped chert masses. The upper third of the preserved Kaibab is dark-blue-gray limestone enclosing large numbers of brownweathering chert lenses. The limestone is fine grained, extremely fetid, and contains large numbers of Permian brachiopods, corals, and bryozoans. R. E. Grant identified the brachiopods as a species of Peniculauris that is similar to, but not the same as, $P$. bassi (McKee). Helen Duncan examined the bryozoans and identified one as Timanodictya and found another suggestive of Bicorbis arizonica. Both are diagnostic of the Kaibab and $\mathrm{K}$ aibab equivalents in the Great Basin.

Paleozoic rocks, undifferentiated-Paleozoic rocks mapped as undifferentiated occur primarily in an almost linear belt west of A pache Wash. These rocks include parts of the Paleozoic section already described, with one exception. Near Dripping Spring is $500+$ feet of mottled gray-and-gold-colored dolomitic limestone that contains small, round structures resembling Girvanella. This dolomitic limestone is very similar to the Cambrian Muav Limestone found in the Grand Canyon. An unconformity bounds the top of the unit and a fault the bottom. The carbonate has not been recognized in the section north of Black Mesa, the lower part of which is more like the southeastern Arizona Paleozoic than the Grand Canyon section.

\section{MESOZOIC(?) ROCKS}

Continental red beds. - Several square miles in the south and central parts of the quadrangle are underlain by continental redbed deposits. The unit is cut by many faults, and the lower contact is nowhere depositional. Sandy maroon mudstone makes up about 50 percent of the unit, sandstone about 40 percent, and pebble conglomerate about 10 percent. Mudstone layers, separated by sandstone or conglomerate beds, range in thickness from a foot to about 100 feet. Sandstone beds are from 1 to 15 feet thick and are white, tan, or pink. Conglomerate beds up to 15 feet in thickness are composed of chert, quartzite, and lime- stone clasts that average about 1 inch in diameter. The greatest nonfaulted section preserved in the quadrangle is about 500 feet thick. As shown on the map and cross-section $\mathrm{C}-\mathrm{C}^{\prime}$, some areas are apparently underlain by greater thicknesses of this unit. These areas, however, are cut by numerous small faults which are not shown.

\section{MESOZOIC OR CENOZOIC ROCKS}

Quartz monzonite porphyry.-An area of about 2 square miles west and northwest of Black Mesa is underlain by a distinctive light-gray quartz monzonite porphyry. The pluton is fault bounded, except on the southeast, and at localities where it is overlain by younger volcanic rocks. The porphyry has a uniform texture and mineralogy. Conspicuous feldspar phenocrysts up to $2 \mathrm{~cm}$ long occur throughout, and smaller phenocrysts of quartz are even more numerous. The groundmass is quartz, plagioclase, and potassium feldspar averaging between $0.2 \mathrm{~mm}$ and $1 \mathrm{~mm}$ in size. Biotite and possibly amphibole were present in small amounts, but are now completely altered to chlorite.

Quartz porphyry._Light-gray quartz porphyry intrudes older rocks at several places in the quadrangle. Three of the intrusions are elongate in outcrop pattern and have a definite northeast trend. The porphyry has an aphanitic groundmass, which encloses euhedral phenocrysts of quartz and plagioclase averaging about $2 \mathrm{~mm}$ in size. All plagioclase is altered to sericite and epidote group minerals. Small crystals of biotite and possibly hornblende have been altered to magnetite, chlorite, piedmontite, and epidote. Potassium feldspar is microcline and in most cases makes up less than 10 percent of the rock. The altered groundmass consists of sericite, quartz, albite, and epidote group minerals. Composition of the rock is probably dacite.

Mafic dikes.-Dark-green, highly altered dikes intrude the continental red beds west of Dripping Spring and the coarsegrained quartz monzonite north of Black Mesa. They range in thickness from about 5 feet to 200 feet. Epidote, albite, tremolite, chlorite, quartz, sericite, and opaque minerals now compose the rock. Original textures are crudely preserved. Grain size is medium to coarse. The dikes are younger than the continental red.beds but older than the Tertiary(?) volcanic rocks.

Latite dike.-A dark-purple-gray latite dike is intruded along the entire west side of the quartz porphyry mass southwest of Dos Picachos. The dike rock has an aphanitic groundmass which contains abundant, highly altered feldspar phenocrysts. This dike may have been emplaced along a preexisting fault separating the quartz porphyry and metavolcanic rocks.

Sedimentary rocks derived from quartz porphyrv.-Several hundred feet of arkose and conglomeratic arkose appear to rest nonconformably on quartz porphyry about 2 miles southwest of Dos Picachos. The clastic rock appears to be derived almost entirely from the porphyry, and where stratification is not obvious, strongly resembles the porphyry. The rock is light gray and consists of poorly rounded but moderately well sorted clasts of feldspar, quartz, epidote, and lithic fragments. Beds are a few inches to about 5 feet thick. The original thickness of the unit is not known because the upper contact is a thrust fault.

\section{LIVINGSTON HILLS FORMATION}

The name Livingston Hills Formation is here introduced for the interbedded sequence of conglomerate, graywacke, and siltstone found in several mountain ranges in Yuma County. At the type locality in the Livingston Hills, most of which lies just outside the southern boundary of the quadrangle, a homoclinal section almost 12,000 feet thick is well exposed. Here, almost the entire Livingston Hills is underlain by the type section which rests unconformably on the continental red beds of Mesozoic(?) age. At other places in the quadrangle, however, it rests on Paleozoic carbonate and hypabyssal intrusive rocks. The upper contact is hidden beneath alluvium. The formation is divided into three members.

The conglomerate member forming the base of the formation is about 4,700 feet thick at the type locality and is composed of massively bedded heterogeneous boulder conglomerate. Conglomerate beds average about 25 feet thick and are separated by thinner, lensoidal beds of arkose or graywacke. Boulders are derived from all older units and range in size from a few inches to over 5 feet; almost all arè angular. The conglomerate grades upward into the graywacke member through increasing numbers of graywacke beds. 
The graywacke member at the type locility is composed of about 5.500 feet of well-lithified medium- to coarse-grained graywacke and conglomeratic graywacke. It is dark to medium gray. Bedding thickness ranges from a few inches to several tens of feet. Quart\%, plagioclase, and rock fragments are the most abundant clasts. Sericitic and calcareous material makes up the bulk of the matrix, which constitutes 20 to 60 percent of the rock.

About 3,300 feet above the top of the conglomerate member is approximately 2.000 feet of siltstone and fine-grained graywacke which intertongues with the graywacke member. About 2,200 feet more graywacke overlies the siltstone. Both the upper and lower contacts of the siltstone member are gradational with the graywacke. Bedding in the siltstone member averages from 1 to 3 inches in thickness, and color is most commonly light gray.

Algae. plant remains, poorly preserved gastropods, and a stomatopod have been found in the Livingston Hills Formation, but none are preserved well enough to be of use in determining the age of the rock. The unit is younger than the continental red bed deposits, but older than the Tertiary(?) volcanic rocks. It is therefore assigned a Cretaceous or Tertiary age.

\section{TERTIARY(?) ROCKS}

Rhyolite-Light-pink to light-gray rhyolite or rhyodacite flows and tuff crop out a mile north of Lazarus Tanks and about 2 miles north of Black Mesa. The rock contains quartz and altered biotite phenocrysts in an altered pink groundmass. Small spherulites and quartz-lined vugs are common. Some of the rhyolite shows banding, but most is massive. It appears to be the oldest rock in the exposed Tertiary(?) volcanic series.

Older basalt.-Amygdaloidal and massive basalt about 1,200 feet thick overlies the rhyolite near the north border of the quadrangle. Flows range in thickness from a few feet to about 50 feet. "Iddingsite" after olivine forms the only phenocrysts visible. Most of the rock is highly altered.

Andesile breccia.-An area of several square miles in the northeast part of the quadrangle is underlain by angular unsorted breccia and interlayered andesite flows. The rock is light pink to gray. Andesite similar to the interlayered flows forms clasts up to $50 \mathrm{fect}$ in diameter in the breccia. Stratification within the deposit is obscurc. Thickness calculated from width of outcrop using the attitude of bounding units is about 2.500 feet.

Older hornblende-biotite andesite.-Overlying, and possibly interfingering with, the andesite breccia is a section up to several thousand feet thick composed of pink, gray, and red-brown hornblende-biotite andesite flow rock. Tuffaceous material is interbedded locally with the andesite flows, especially near the base. Hornblende, biotite, and plagioclase crystals averaging 1 or $2 \mathrm{~mm}$ in size are common in most of the andesite and are easily seen in hand specimen. In most cases the groundmass is a microcrystalline mixture of plagioclase. glass, and opaque minerals. Textures range from trachytic to hyalopilitic.

Biotite andesite.-A small mass of biotite andesite is present just east of Dripping Spring. The andesite is in part intrusive and in part extrusive. Small biotite and plagioclase phenocrysts are set in a light-tan to light-gray groundmass of plagioclase, with lesser amounts of opaque minerals and glass. Pyroxene crystals intermediate in size between the groundmass and phenocrysts are common but not abundant. Texture is trachytic to pilotaxitic.

Hornblende-biotite andesite.-Between 200 and 400 feet of dark-gray to black hornblende-biotite andesite unconformably overlies the andesite breccia and the older hornblende-biotite andesite. Individual flows appear to be about 50 feet thick and have glassy borders. Small phenocrysts of hornblende, biotite, and plagioclase are present in most of the rock. Plagioclase, glass, and opaque minerals make up the groundmass. The present topography was developed, at least in part, at the time of extrusion, for the lavas are found at very different elevations and appear to buttress against the older volcanic rocks.

\section{TERTIARY OR QUATERNARY ROCKS}

Basalt of Black Mesa.-Black Mesa, in the east central part of the quadrangle, is underlain by Tertiary or Quaternary olivinebearing basalt. The basalt is divisible into two parts: a lower unit containing interbedded tuffaceous rocks and an upper unit of basalt flows only. In the lower unit the tuff beds average about 10 feet thick, but some are as much as 50 feet thick. Thickness of individual flows is from 20 to 50 feet in both units. Basalt of the two units appears to be identical. Labradorite constitutes 50 to 60 percent of the rock: diopsidic augite, 35 to 45 percent: olivine $\left(\mathrm{Fo}_{78-82}\right), 5$ percent; and opaque minerals about 1 percent. Thickness of the lower unit is estimated at 400 to 500 feet, that of the upper unit at about 700 feet.

Older alluvium.-Fifteen to 20 square miles along the eastern edge of the quadrangle is underlain by unconsolidated to poorly consolidated older alluvium. It consists of completely unsorted blocks of all bedrock units in a matrix of arkose and lithic arkose. Stratification within the deposit is obscure. The older alluvium is distinguished from the recent alluvium only by its topographic expression and appearance on aerial photographs.

Alluvium and taius.-Alluvium and talus are not separated in the Quartzsite quadrangle. Included in the undifferentiated unit is all surficial debris in present drainage channels. on talus slopes, on alluvial fans, on the broad areas of desert pavement, and on the La Posa Plain. Most of the material consists of a heterogeneous mixture of angular, unsorted boulders, cobbles, sand, and smaller sized material.

\section{ROCKS OF UNKNOWN AGE}

Granitic rocks of the Dome Rock Mountains.-Granite Mountain, the easternmost part of the Dome Rock Mountains, is underlain by at least three different plutonic rocks. Probably the oldest is a pervasively sheared pink quartz monzonite. This rock is intruded by an essentially unsheared biotite quartz monzonite. Forming a small outlier from the main mountain is a dark-colored, slightly sheared biotite-rich quartz monzonite. The age of these rocks and their extent beyond the quadrangle are unknown.

\section{REFERENCES}

Cooper, J. R., and Silver, L. T., 1964, Geology and ore deposits of the Dragoon quadrangle, Cochise County, Arizona: U.S. Geol. Survey Prof. Paper 416. $196 \mathrm{p}$.

Hayes, P. T., and Landis, E. R., 1965, Paleozoic stratigraphy of the southern part of the Mule Mountains, Arizona: U.S. Geol. Survey Bull. 1201-F, 43 p.

Ransome, F. L., 1904, The geology and ore deposits of the Bisbee quadrangle, Arizona: U.S. Geol. Survey Prof. Paper 21, $168 \mathrm{p}$. 